\title{
Phytoremediation: An Urban Landscape Strategy for Sustainable and Healthy Cities
}

\author{
Maria Estela Ribeiro Mendes ${ }^{1, a}$, Silvia Mikami G. Pina ${ }^{2}$ \\ ${ }^{1,2}$ University of Campinas- UNICAMP, Architecture, Technology and City Graduate Program, School of Civil Engineering, Architecture \\ and Urban Design, Rua Saturnino de Brito, 224 Cidade Universitária Zeferino Vaz, Campinas -SP, 13083-889.
}

\begin{abstract}
Phytoremediation is a natural technique which explores the interactions between bacteria located in rhizosphere and diverse types of contaminants (organic and inorganic), in other words, it is the use of living plants to remove, reduce or immobilize contaminants in water, soil and sludges. Natural processes act in water and soil depuration spontaneously through the molecules' chemicals transformations, resulting in a nontoxic substance. Cities worldwide are faced with the challenge of contaminated water, soil and air, exposing urban dwellers to several types of pollution destructive to the humans and to the city's health. By integrating phytoremediation and urban landscape it is possible to develop a multifunctional green infrastructure network, capable of mitigating problems related to water management and urban pollution. This paper provides a literature review that aims to recognize phytoremediation's technical collaboration to a water sensitive urban design into sustainable cities, and join these important concepts to urban landscape practices, less known in Brazilian municipalities.
\end{abstract}

Keywords. Phytoremediation; Sustainable Cities; Urban Landscape; Green Infrastructure.

\section{Introduction}

Cities worldwide are faced with the challenge of contaminated water, soil and air. Urban dwellers are directly exposed to diverse types of pollution potentially harmful to health. Studies performed by University of São Paulo - USP ${ }^{1}$ have shown that urban pollution kills indirectly eight people per day in the city of São Paulo alone. Worldwide, at least three billion people are consuming contaminated water, and, according to World Health Organization - $\mathrm{WHO}^{2}$, more than five million people have been dying annually in consequence of waterborne diseases.

Over the last few decades, Brazilian cities have suffered with the consequences of mismanagement urban sprawl and a high environmental impact due to industrial development. Ecosystem services in urban areas have deteriorated and green areas were replaced for impervious surfaces. Perhaps, the most significant changes came from atrophic actions that can be identified in hydrological regimes, water cycle and sanitation conditions.

\footnotetext{
${ }^{1}$ Research from 2005, realized at Experimental Atmospheric Pollution laboratory - Medicine School, University of Sao Paulo, led by Professor Paulo Saldiva.

${ }^{2}$ World Health Report 2008: Primary Health Care - Now more than ever.
}

In several cities of the country, industrial and domestic effluents are dumped into rivers, lakes and streams without any caution, in other words, no treated sewage reaches clean water every day. This is the main form of surface water contamination. However, degradation of water resources also occurs indirectly by waste, soil, and air pollution; rainy events act like a wide basin surface washout, in this way runoff carries a vast pollutant amount (ISHIMATSU et al, 2017).

The major contribution of contaminated surface runoff is from the first minutes of rainfall, named firs flush. Roofs, streets, parking lots and impervious surfaces retain sediments and associated pollutants day by day, during storm water events when rainfall depth reaches $\approx 0,013 \mathrm{~m}$, a large dragging capacity is identified and contaminated urban surfaces are washed out. Through this vision, it is possible to identify that urban pollution is divided into two groups: (1) punctual pollution and (2) diffuse pollution. The first one is associated to specific contributions, concentrated locally, making it easier to monitor and control the pollution load. The second one is characterized by diverse types of contribution sources dragged by runoff during stormwater events, acting in an unpredictable way (SCHUELER, 1987).

At first, it was believed that the cause of urban water body degradation resulted merely from dumping untreated sewage, however, surface runoff represents a significant contribution to pollution loads on water

\footnotetext{
a Corresponding author: me.ribeiromendes@gmail.com
} 
bodies and wetlands, it is estimated that $25 \%$ of water contamination comes from diffuse pollution. Facing this issue, new practices are emerging to improve pluvial and fluvial integrated water handling as part of urban environmental management, linking natural resources regeneration to architecture landscape and green infrastructure (SCHIVARTCHE, 2005).

Green areas are important to improve water surface quality. Vegetation has the capacity to retain pollutants, collaborating to both sedimentation and infiltration phenomenon and promotes depurative biological process. Diverse water management approaches have been tested since the industrial revolution. An evolution line can be traced from traditional engineering sewer systems to a new best practice in sensitive urban water design (SUDS) ${ }^{3}$. A novel vision has been reveling a holistic concern beyond local approach, considering the complete hydrographic basin and recognizing the urban water as protagonist (ANDRADE; BLUMENSCHEIN, 2014).

The cities' sustainable development should be related to an integrated water management in municipal governance. Alternatives to mitigate and control urban pollution and guarantee water quality through environmental optic are essential to preserve water as life support (TUCCI, 2008). Progressively, cities are becoming examples when entering the vanguard of sustainability by applying alternative solutions to varied urban concerns. In this context, biotechnology has improved with the purpose of igniting ecological movement through 'sustainable urbanism' defending principles, linking urban design to nature (FARR, 2013).

New typologies of green infrastructure are adopted as an alternative to urban drainage, mimetizing the soil natural capacity of absorption and infiltration, collaborating to hydraulic stability. Natural systems design combined with landscape projects represents a holistic view, capable of preventing, treating, and to storage the contaminated runoff, expanding the performance beyond water quality, but also, a resilience mechanism between human and nature.

Natural processes act in water depuration spontaneously, directly influencing their quality maintenance. The technic that explores interaction properties between bacteria located in the plant rhizomes and diverse types of contaminants (organic and inorganic) is called phytoremediation. In other words, it is the use of living plants to remove, reduce or immobilize contaminants in water, soil, sludges and even the air. Natural interactions at root zone promote chemical molecules transformations, resulting in a nontoxic form, which is environmentally harmless (ANSARI et al, 2015).

\footnotetext{
${ }^{3}$ Water sensitive urban design is an approach to the planning and design of urban environments that is 'sensitive' to the issues of water sustainability, resilience and environmental protection. The approach integrates the urban water cycle (including potable water, wastewater and stormwater) into built and natural landscapes to provide multiple benefits to society (ANDRADE; BLUMENSCHEIN, 2014).
}

Root zone (rhizosphere) treatments are already recognized and understood, but phytoremediation mechanism is viewed isolated from urban landscape design (TODD; KELLY, 2016). Usually environmental engineers, remediation specialists, chemistry professionals and even botanicals are the experts involved with the implementation of phytoremediation systems, including constructed wetlands, using this potent instrument entirely as a remediation process without considering that the huge protagonists are plants. Traditionally, green spaces design belongs to landscape architects, so can't phytoremediation be seen beyond depurative abilities and integrate urban landscape into a green infrastructure multifunctional ${ }^{4}$ network?

Integrating phytoremediation into the urban landscape is a strategy to achieve a gradual improvement of the city's health. There are many benefits associated with green infrastructure sprawl that enhance the quality of life in the surrounding neighborhoods and the hole city, when implemented as an open green spaces network (HERZOG, 2016). This article has the following objectives: (a) recognize phytoremediation's technical collaboration to urban landscape practices; (b) introduce the phytoremediation technique as an urban landscape strategy to improve city health; and (c) describe green infrastructure typologies destined to improve both water management and quality, in addition to green spaces advantages.

\section{Phytoremediation: depollution plants}

Vegetation acts directly on hydrologic variations, mainly through plant interception by treetop, leaves, trunks, and roots. Retention capability varies between $10 \%-20 \%$ from total annual precipitation (MANNING, 1992). In the cities, vegetable interception areas can be designed in combination with wetlands, aiming retention and storage of pluvial water precipitation, this arrangement is called soil abstraction and can be applied in green infrastructures as bioswales, rain gardens, boulevards, parks and squares. The combination between urban landscape and hydraulic mechanisms represents a new possibility to equilibrate urban water handling and other diverse functions, such as: beauty, recreation, abandoned urban areas regeneration, environmental valuation, air quality improvement, decrease of thermal amplitudes, as well as supporting biodiversity development, strengthening the ecosystem and inducing resilience.

The combination between drainage systems and public green areas are strategical not only based on revitalization or city appreciation, but based on the possibility to plan distributed actions through the basin, contrasted to traditional centered engineering drainage network. There is also a major viability to construct natural drainage systems mixed with urban landscape

\footnotetext{
4 Multifunctional landscape: same area with different objectives and functions regarding ecological, economic, cultural, social and aesthetic interests (MIGUEZ et al, 2016, p.19).
} 
when we consider public financing and investment in multifunctional spaces, not to mention public acceptance which is exponentially superior when compared to traditional constructions due to social gain and life quality improvement (MOURA, 2013).

The combination of phytoremediation technic and urban landscape represents an important strategy to reduce contamination rate to appropriate levels for human health while minimizing the pollution dissemination and fulfilling an important infrastructural leading figure to urban water management, climate change and biodiversity development (MAHLER, 2007).

Vegetation presence stimulate macrobian activity and underground development through exudates from roots, which provide nutrients to microorganisms, also through decomposing plant matter, which enriches the soil with carbon and more nutrients by favorable environmental conditions such as shading and increase of soil moisture. Biodegradation (organic composts) is considered an indirect action, but can also occur in a direct way across internal plant metabolization or root enzymes. The species resilient to this ambient are known as macrophytes and comprise all the plants, which keep the photosynthetically active parts submerged all the time, for a period, or floating plants.

Worldwide, the applications of the phytoremediation technique in projected systems are known as constructed wetlands. Vymazal (2008) classifies constructed wetlands in three main types: floating, submerged and emergent, the last one can be further subdivided into two other classifications: (1) surface flow and (2) sub-surface flow (horizontal, vertical and hybrids).

In vertical sub-surface flow wetlands, higher hydraulic conductivity occurs because the substrate does not remain constantly saturated, so the root zone is characterized as an aerobic environment. Oxygen presence allows the occurrence of important chemical processes such as nitrification and mineralization of the organic deposits resulting from Total Suspended Solids (TSS), the aerobic ambient also promotes the removal of BOD and COD, Phosphorus, Ammonia, Nitrite and Sulfide.

On the other hand, in horizontal sub-surface flow wetlands, higher hydraulic stability occurs because the water is permanently stored into substrate, promoting an anaerobic environment. As a result, due to its limited oxygen transfer capacity, there is a major efficiency in the removal of pollutants such as Nitrate, Sulfate and BOD in secondary and tertiary treatment. This step is very satisfactory in the removal of suspended solids and bacteria. Finally, in surface flow wetlands there is a great amount of organic matter and suspended solids removal resulting from hydraulic efficiency (low flow velocity and high storage time) and good sedimentation conditions (SILVA, 2007).

In this way, phytoremediation technique applied to constructed wetlands is capable of effectively reduce or remove, high levels of pollutants in contaminated water, including organic matter and inorganic matter, soluble and particulate matter, nitrogen, phosphorus, pathogens and heavy metals. The reduction of these concentrations occur through different treatment mechanisms favored by the interaction between substrate and soil, plants and symbiotic microorganisms at root zone, which are: sedimentation, filtration, precipitation, adsorption, microbial interactions and absorption by vegetation (MENDONÇA, 2015).

Table 1. Pollutant removal mechanisms through constructed wetlands tradicionally found in contaminated water. Source: MENDONÇA, 2015, p. 42.

\begin{tabular}{|c|c|}
\hline Pollutants & Removal mechanisms \\
\hline $\begin{array}{l}\text { Total Suspended Solids } \\
\text { (TSS) }\end{array}$ & $\begin{array}{l}\text { Sedimentation } \\
\text { Filtration }\end{array}$ \\
\hline $\begin{array}{l}\text { Soluble organic matter } \\
\text { (SOM) }\end{array}$ & $\begin{array}{l}\text { Aerobic and anaerobic } \\
\text { biological degradation }\end{array}$ \\
\hline Nitrogen $(\mathrm{N})$ & $\begin{array}{l}\text { Metabolization by plant } \\
\text { Ammonification } \\
\text { Biological nitrification and } \\
\text { denitrification }\end{array}$ \\
\hline Phosphor (P) & $\begin{array}{c}\text { Adsorption } \\
\text { Metabolization by plant } \\
\text { Adsorption and cation } \\
\text { exchange }\end{array}$ \\
\hline Pathogens & $\begin{array}{c}\text { Predation } \\
\text { Natural death } \\
\text { UV irradiation }\end{array}$ \\
\hline Metals & $\begin{array}{c}\text { Complexation, precipitation } \\
\text { Absorption by plant } \\
\text { Biochemical Oxidation and } \\
\text { Reduction } \\
\text { Sedimentation } \\
\text { Filtration }\end{array}$ \\
\hline
\end{tabular}

Wetlands are extremely important ecosystems on biological processes maintenance and life support, landscape act as livers act to human body, because wetlands have essential functions to hydrological cycle due to the capacity to control and retain floods, water storage, and increase of its quality through depurative properties. Wetlands presents a series of functions and values, according to Davis (1994): Improvement of water quality, flood storage, desynchronization between storm and surface runoff, nutrient cycling (organic compounds), habitat for aquatic life, passive recreation areas, education and research, aesthetics and landscape enhancement.

\section{Green Infrastructures: a multifunctional landscape}

Around the world, urban landscape has been increasingly considered beyond aesthetic function. In cities like Seattle and Portland, for example, it is designed as an integrant part of an open green network 
associated to technologies, projected to solve urban problems related to water, climate change, and ecology. This planning presents an exciting potential to positively impact the environmental quality of consolidated urban areas because natural systems easily compose urban infrastructures: green roof, bioswales, parks, squares, rain garden and other city elements.

The development of a landscaping with hydrological functions integrated to the phytoremediation mechanism represents the opportunity to create a new urban design, focused on ecology, enhancement of local biodiversity, and make it possible to recover abandoned or degraded areas. In the vision of ecological urbanism, there is a concern to introduce and maintain the natural elements in the city which is why the design of the drainage systems are directed to the water retention to retard their downstream release, favoring infiltration and reuse (MGUNI et al, 2015).

Runoff must be considered polluted water because it concentrates precipitated atmospheric pollutants (gases) and leachate from urban soil (hydrocarbons and suspended matter). The impacts of polluting sources on the urban environment and urban water resources were summarized by Moura (2013), which lists some water quality indicators: Dissolved oxygen (DO), biochemical oxygen demand (BOD) and chemical oxygen demand (COD).

Green infrastructures aim to accumulate water drained from the basin, increasing the time of drainage and amortizing the floods. It results in a lower incidence of flooding. In addition, due to purifying capacity of the plants and associated microorganisms (phytoremediation), clean water infiltrates into the soil to recharge aquifers or it is sent to rivers, seas and other water bodies with a better quality, since the pollutants are removed by adsorption, filtration, volatization, ion exchange and decomposition. During rainfall events that exceed the storage capacity of bioswales or rain gardens, the water flow goes directly to the traditional drainage system (SCHOLZ et al, 2007).

Phytoremediation can also improve rivers' water quality. As we know, no treated water reaches clean water every day: sewage, solid waste, diffuse pollution; the excessive organic load in water decreases the rate of dissolved oxygen, resulting in unpleasant odor and mortality among fish and other aquatic life. In this type of intervention, it is possible to adopt floating structures above the river itself or adjacent gardens that are in direct contact with water; in both cases, the maintenance of the water quality occurs through the auto depurative capacity in the integration between plants, microorganisms and water.

These projects should be implemented as part of the revegetation of the margins (riparian forest), promoting (1) the soil stabilization due to roots and humidity control, (2) the barrier function or a filter in the control of the runoff, and (3) the sediment loading resistance to the river (VALIPOUR \& AHN, 2015).

\subsection{Bioswales}

Cut soil structure based-designed on trapezoidal or parabolic section. This drainage system is capable to transport surface runoff at low speed due to small inclination bottom. These factors promote a larger time of concentration and a lower water flow speed, decrease of peak discharge and flow rate, increase of soil infiltration and qualitative improvement of water.

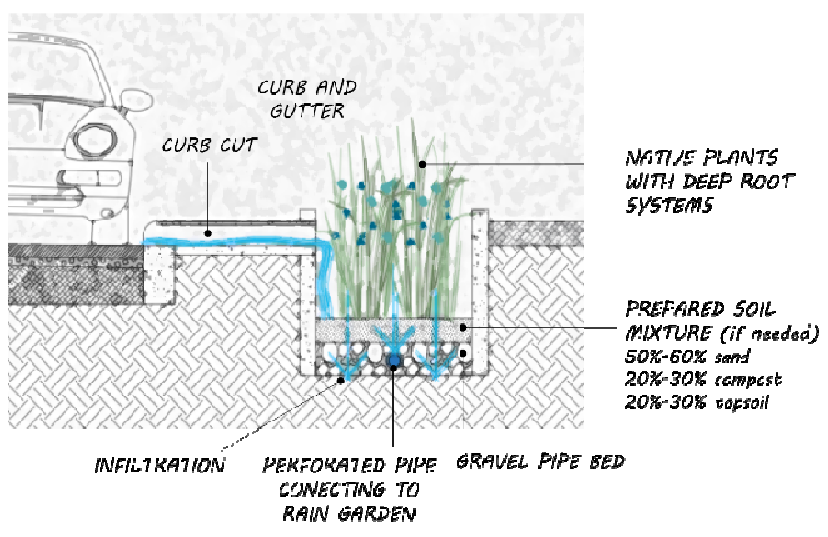

Figure 1. Bioswale profile. Source: Author, 2017.

\subsection{Rain Gardens}

Cut soil structure filled with high-permeability granular material and vegetation. This green infrastructure aims to biorretention, storage, treatment, evapotranspiration and infiltration of rainwater, besides landscape beauty and environmental value. Rain gardens promote the reduction of volume, flow and surface runoff, storage and treatment of water, high levels of infiltration, recharge of the sheet and return of water to the natural cycle.

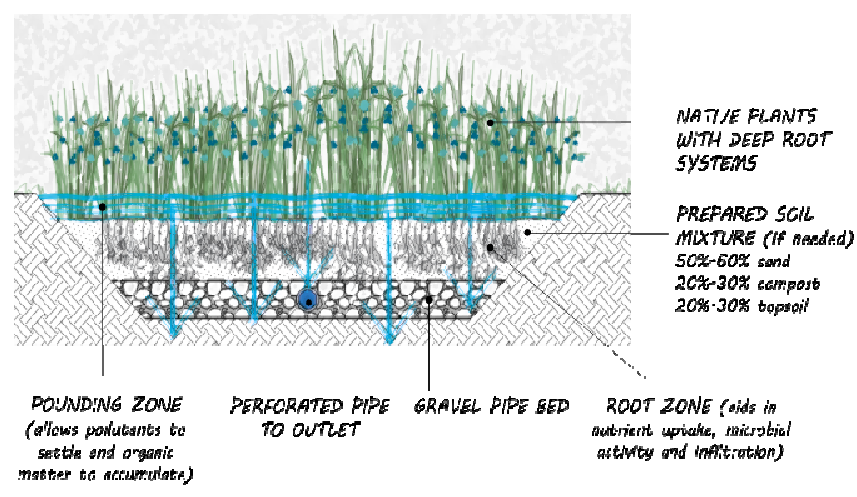

Figure 2. Rain garden profile. Source: Author, 2017.

\subsection{Pluvial Wetlands}

Cut soil structure designed to retain long runoff, maintaining a dead volume (pond) permanently. These 
set promotes self-depuration through physical and biological mechanisms, as well as reducing volume, and it treats water quality. Pluvial wetlands promote quantitative control of urban floods (volume), qualitative control of water (sedimentation and biological decomposition) and reduction of contaminant downstream.

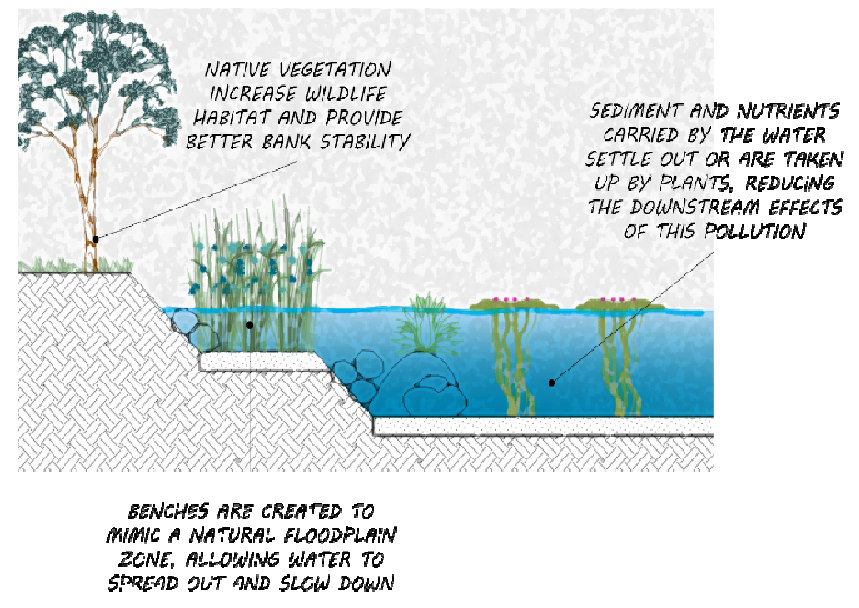

Figure 3. Pluvial wetland profile. Source: Author, 2017.

\subsection{Green Roofs}

Vegetable structure under built surfaces designed to increase permeable areas in cities. Although it is a technique that doesn't allow direct infiltration, it is possible to amortize surface runoff and brings benefits to the environment. Green roofs are a useful green area and urban revegetation, besides reduces water volume sent to the drainage system and brings rainwater back to its natural cycle.

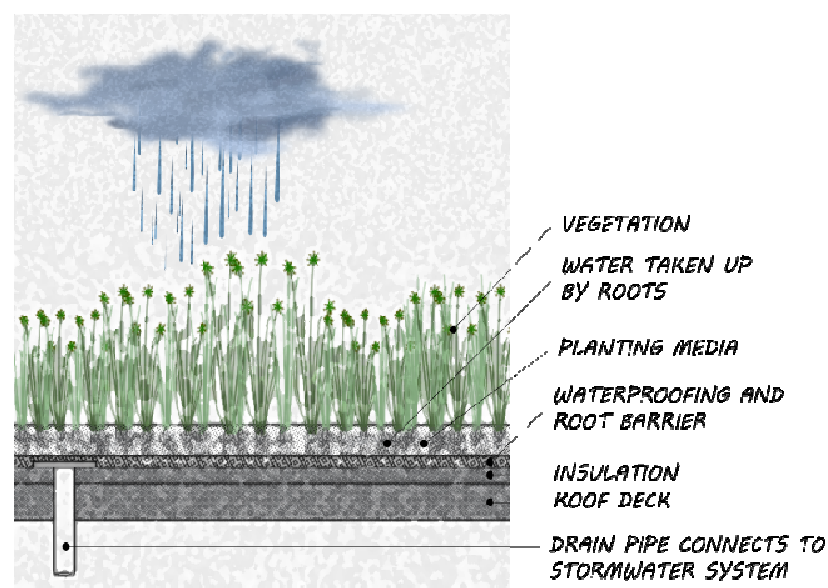

Figure 4. Green roof profile. Source: Author, 2017.

\subsection{Floating Islands}

Thermo-fused tough floats laid on rivers and lagoons to provide natural water quality improvement through extended roots structure beneath the water, which promote the establishment of beneficial aquatic biofilms that cleanse the water through the breakdown, sorption and metabolic transformation of nutrients and impurities. The versatile modular structure can be customized to hundreds of shapes and sizes, attending different demands. Furthermore, adding beauty to any waterscape or waterfront with native and selected plant species, floating islands can increase ecological water restoration processes.

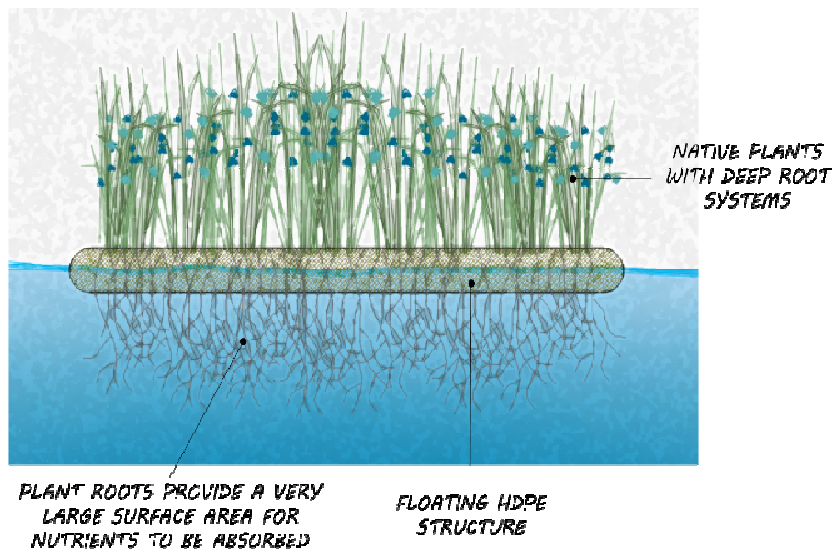

Figure 5. Floating wetland. Source: Author, 2017.

\subsection{Riverbanks}

Floating modular ecosystem structures made with stainless steel \& $\operatorname{HDPE}^{5}$ (non-biodegraded). Designed to improve water quality within rivers and canals promoting the increase of aquatic life through diversity: microorganism, plants, algae, fish. Biodiversity brings strength to the river that becomes more resilient to inevitable inflows of pollution (agricultural, runoff, sewage or industrial contributions). Riverbanks revitalize waterway, its incorporation works against high nutrient levels, eutrophication, and mitigation of odors and promote increased beauty, visitor's attraction and riverside property value.

\footnotetext{
${ }^{5}$ HDPE (High-density polyethylene) is a polyethylene thermoplastic made from petroleum. It is the most common plastic due to corrosion-resistant capacity.
} 


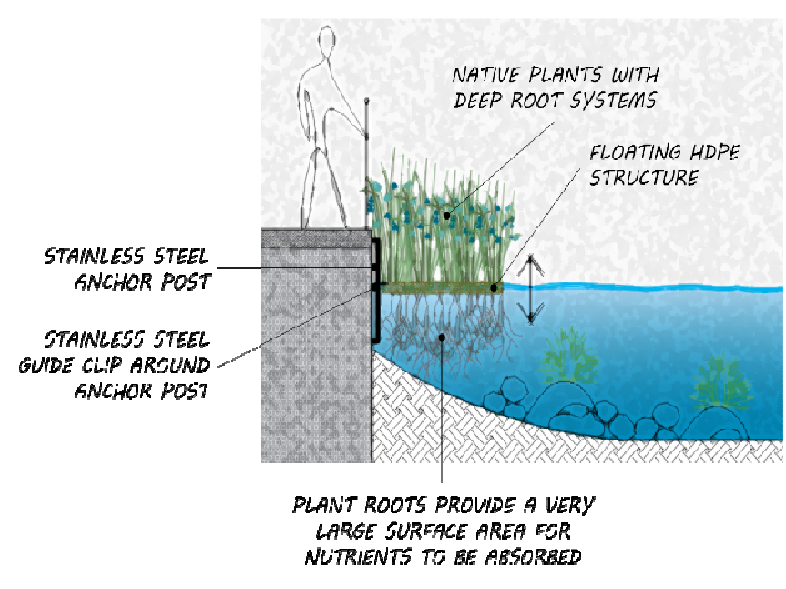

Figure 6. Riverbank profile. Source: Author, 2017.

\section{Conclusion}

The primary goal of this study was to explore phytoremediation as a strategy to urban landscape to improve environmental quality through green infrastructures; in addition to the remediation efficiency, phytoremediation has the potential to be seen beyond integrating multifunctionality to the cities green areas. The benefits of green spaces are numerous, among them is the (1) approximation of people, who begin to interact more as they use a common space; (2) real estate valuation, due to thermal and visual comfort; and (3) improving pollution parameters in the local environment (HERZOG \& ROSA, 2010).

The typological variations of green infrastructures allow design flexibility, adapting to the demands of the region. There are several benefits, as it combines depurative functionality with the appreciation of architecture and urban landscape, turning them into public spaces that are accessible to the public. In addition, it represents an important ecological role with the creation of areas that stimulate the growth of fauna and flora, enriching the local ecosystem. Precautions were also observed, among them is the question of clogging and high demand of empty areas.

Table 2. Advantages and precautions of phytoremediation techinique integrated to urban landscape. Source: Author, 2017.

\begin{tabular}{|c|c|}
\hline Advantages & Precautions \\
\hline $\begin{array}{c}\text { "In situ" technique } \\
\text { application }\end{array}$ & $\begin{array}{c}\text { Empty areas required } \\
\text { (green areas included) }\end{array}$ \\
\hline $\begin{array}{c}\text { Natural and efficient } \\
\text { process, requires no } \\
\text { chemical or complex } \\
\text { equipment }\end{array}$ & $\begin{array}{c}\text { Limited plant capacity } \\
\text { support due high } \\
\text { contaminated levels } \\
\text { (concentration x area) }\end{array}$ \\
\hline
\end{tabular}

\begin{tabular}{|c|c|}
\hline $\begin{array}{c}\text { Considering organic } \\
\text { compounds treatment, the } \\
\text { biomass resulting from } \\
\text { pruning can be reused as } \\
\text { fertilizer and similar } \\
\text { purposes }\end{array}$ & $\begin{array}{c}\text { Over time, clogging } \\
\text { phenomenon is noted, it is } \\
\text { variable with local sediment } \\
\text { transport, but invariable } \\
\text { substrate substitution is } \\
\text { necessary }\end{array}$ \\
\hline $\begin{array}{c}\text { Low environmental impact, } \\
\text { runoff volume amortization } \\
\text { and water quality } \\
\text { improvement }\end{array}$ & $\begin{array}{c}\text { Natural open system } \\
\text { process (plants growth out } \\
\text { of human control, non- } \\
\text { immediate robust } \\
\text { rhizosphere) }\end{array}$ \\
\hline $\begin{array}{c}\text { Efficiency in a variety of } \\
\text { pollutants removal: fine } \\
\text { sediments, metals, nutrients } \\
\text { and bacteria }\end{array}$ & $\begin{array}{c}\text { Bioaccumulation toxicity } \\
\text { considering heavy metals } \\
\text { incident (large scale) }\end{array}$ \\
\hline $\begin{array}{c}\text { Low cost and low } \\
\text { complexity of operation and } \\
\text { maintenance }\end{array}$ & \\
\hline
\end{tabular}

Phytoremediation is not a solution to urban problems related to water pollution, it is rather a complementary and mainly preventive action. Mitigation is a strategy to urban floods and attacks the problem in its cause, revealing a systemic vision that seeks distributed landscape actions to reduce and delay flood spikes, water table recharge and natural runoff restauration. Rainwater management through compensatory techniques consider the impacts of urbanization in a global way, taking the basin as study base. In addition, compensatory techniques are seeking to systematically compensate the effects of urbanization by controlling runoff from impervious surfaces at it's origin (through infiltration) and avoiding its rapid downstream transfer through temporary storage structures (concept of reservation). When integrating phytoremediation to compensatory drainage techniques, the presence of aquatic macrophytes is beneficial and shows a significant and positive effect on the removal of pollutants, since they offer a large surface area for the fixation and growth of microorganisms (biofilm), provide organic carbon and oxygen on root zone, reduce the flow velocity, promote filter bed stabilization, and maintenance of hydraulic conductivity (SCHOLZ et al, 2007).

Sustainable cities are adopting alternatives in smart urban landscape planning. Integration between environmental, social and economic aspects are key to promote harmony between a prosperous life without overburdening natural resources. Therefore, this holistic view presents phytoremediation as a strategy of landscape architecture, considering that it is capable to improve environmental quality in an economically efficient and socially inclusive way, while promoting the increase of green areas in the city.

\section{References}

ANDRADE, L. M. S.; BLUMENSCHEIN, R. N. A nova Ecologia da Cidade: uma conexão importante para a ciência do 
Desenho Urbano. A dimensão ambiental da cidade. Anais... , 2014. Belém.

ANSARI, A. A.; GILL, S. S.; GILL, R.; LANZA, G. R.; NEWMAN, L. Phytoremediation: Management of Environmental Contaminants. Springer International Publishing, 2015.

DAVIS, L. A Handbook of Constructed Wetlands, 1994. Washington, DC: U.S. G.P.O.

FARR, D. Sustainable Urbanism: Urban Design with Nature. John Wiley \& Sons, 2013.

HERZOG, C. P. A multifunctional green infrastructure design to protect and improve native biodiversity in Rio de Janeiro. Landscape and Ecological Engineering, v. 12, n. 1, p. 141150, 2016.

HERZOG, C. P.; ROSA, L. Z. Infraestrutura verde: sustentabilidade e resiliência para a paisagem urbana. Revista Labverde, p. 92-115, 2010.

ISHIMATSU, K.; ITO, K.; MITANI, Y. Use of rain gardens for stormwater management in urban design and planning. Landscape and Ecological Engineering, v. 13, n. 1, p. 205212, 2017.

MAHLER, J. C. Fitorremediação: O uso de plantas na melhoria da qualidade ambiental. Oficina de Textos, 2007.

MANNING, W. J. Assessing the effects of zone on plants: Use and misuse of ethylenediurea (EDU). Proceedings of the 85th Annual meeting and exhibition on air and waste management association, v. 11, 1992.

MENDONÇA, A. A. J. DE. Avaliação de um sistema descentralizado de tratamento de esgotos domésticos em escala real composto por tanque séptico e wetland construída híbrida, 2016. Dissertação de Mestrado, São Paulo: Universidade de São Paulo.

MGUNI, P.; HERSLUND, L.; JENSEN, M. B. Sustainable urban drainage systems: examining the potential for green infrastructure-based stormwater management for Sub-Saharan cities. Natural Hazards, v. 82, n. S2, p. 241-257, 2016.

MIGUEZ, M. G.; VERÓL, A. P.; REZENDE, O. M. Drenagem Urbana. Do Projeto Tradicional à Sustentabilidade. Brasil: Elsevier, 2016.

MOURA, N. C. B. Biorretenção: tecnologia ambiental urbana para manejo das águas de chuva, 2014. São Paulo: Universidade de São Paulo.

SCHIVARTCHE, F. Poluição urbana: as grandes cidades morrem: você pode salvá-las. São Paulo: Editora Terceiro Nome \& Mostarda Editora, 2005.

SCHOLZ, M.; HARRINGTON, R.; CARROLL, P.; MUSTAFA, A. The integrated constructed wetlands (ICW) concept. Wetlands, v. 27, n. 2, p. 337-354, 2007.

SCHUELER, T. R. Controlling Urban Runoff: A Practical Manual for Planning and Designing Urban Best Management Practices. Washington, D.C.: MWCOG, 1987.

SILVA, S. C. DA. "Wetlands Construídos" de Fluxo Vertical com Meio Suporte de Solo Natural Modificado no Tratamento de Esgotos Domésticos, 2007. Tese de Doutorado, Brasília: Universidade de Brasília.

TODD, L. F.; LANDMAN, K.; KELLY, S. Phytoremediation: An interim landscape architecture strategy to improve accessibility of contaminated vacant lands in Canadian municipalities. Urban Forestry \& Urban Greening, v. 18, p. 242-256, 2016.
TUCCI, C. E. Águas Urbanas. Estudos Avançados, v. 63, n. 22, p. 97-112, 2008

VALIPOUR, A.; AHN, Y.-H. Constructed wetlands as sustainable ecotechnologies in decentralization practices: a review. Environmental Science and Pollution Research, v. 23, n. 1, p. 180-197, 2016.

VYMAZAL, J. Wastewater treatment in constructed wetlands with horizontal sub-surface flow. New York: Springer, 2008. 